\title{
Relationship between Socio-Economic Traits of Women Trainees with their Income Generation by Krishi Vigyan Kendra, Chomu (Jaipur) Rajasthan
}

\author{
Rakesh Kumar Kansotia ${ }^{1 *}$, Jagdish Prasad Yadav ${ }^{1}$, Ajit Kumar Ghoslya ${ }^{1}$, \\ Nitesh Kumar Tanwar ${ }^{2}$ and Naresh Kumar Kumawat ${ }^{3}$ \\ ${ }^{1}$ Department of Extension Education, SKNAU, Jobner, India \\ ${ }^{2}$ Department of Extension Education, MPUAT, Udaipur, India \\ ${ }^{3}$ Department of Extension Education, SKRAU, Bikaner, India \\ *Corresponding author
}

\begin{tabular}{l} 
K e y w o r d s \\
Women, \\
$\begin{array}{l}\text { Income generation, } \\
\text { Vocational } \\
\text { training }\end{array}$ \\
Article Info \\
$\begin{array}{l}\text { Accepted: } \\
\text { 05 February } 2020 \\
\text { Available Online: } \\
10 \text { March } 2020\end{array}$ \\
\hline
\end{tabular}

\section{A B S T R A C T}

Women are the backbone of a family by getting technical knowledge through vocational training and may change their whole life. They will utilize all their mind power by use of new techniques, they also make them self - depend. The study was conducted in Jaipur district of Rajasthan. A list of vocational training and trained women was prepared with help of SMS of KVK Chomu. A sample of 105 women trainees was randomly selected from all 753 women trainees from different agricultural aspects for recording their responses towards their empowerment. The age, caste and type of house were found to have non-significant relationship with income generation of trained women. The occupation, education level, social participation, marital status, size of land holdings, mass media participation, vocational trainings received, economic motivation, market orientation and risk orientation were found to have significant relationship with income generation of trained women.

\section{Introduction}

Income generating activities are considered as those initiatives that affect the economic aspects of people's lives through the use of economic tools such as credit. It is being increasingly realized that women's income in a family is very important in relation to the nutritional, economic and educational upliftment of the family. Empowerment is a multi-dimensional process which should enable women or group of women to realize their full identity and power in all spheres of life. "Empowerment comes from Women's groups who seek to empower themselves through greater self- reliance.

They have right to determine their own choices in life. They also seek to gain control and access to resources". Through vocational 
trainings various changes occur in women behaviors like:

Enhanced self-esteem and self-confidence in women.

Build a positive image of women by recognizing their contribution to the society and economy.

Develop in them an ability to think critically.

Foster decision-making action through collective process.

Enable women to make informed choices in areas like education, employment and health.

Ensure equal participation in development process.

\section{Materials and Methods}

The study was conducted in the Jaipur district of Rajasthan. The samples of the study were selected by two stage sampling method. These were - (1) Selection of Krishi Vigyan Kendra (KVK) (2) Selection of respondents. KVK Chomu was selected purposely because this is one of the oldest (1992) KVK working under NGOs (Non-Government Organizations) in Rajasthan where maximum numbers of vocational women trainings (753) were organized for women empowerment and 17853 women were trained in different professional aspects in the last twenty years from 1996 to 2016 (Annual report of ATARI, Jodhpur). A list of all vocational trainings conducted by KVK Chomu for women empowerment was prepared with the help of SMS of KVK Chomu. Total 695 rural women were trained in different vocational aspects related to agriculture purpose (fruit and vegetable preservation, nursery raising and dairy farming) during last five years (2011-12 to 2015-16) 15 per cent (105) trained women were selected randomly for the study.

\section{Correlation coefficient}

The correlation coefficient (' $r$ ' value) was used to measure the relationship between dependent and independent variables. The correlation coefficient between two groups was calculated by using the following formula.

$$
\mathrm{r}=\frac{\sum_{\mathrm{xiyi}}-\left(\sum_{\mathrm{xi}}\right)\left(\sum_{\mathrm{yi}}\right) / \mathrm{N}}{\sqrt{\sum_{\mathrm{xi}}{ }^{2}-\left(\sum_{\mathrm{xi}}\right)^{2} / \mathrm{N}} \sqrt{\sum_{\mathrm{yi}}{ }^{2}-\left(\Sigma_{\mathrm{yi}}\right)^{2} /}}
$$

Where,

$\begin{array}{lll}\mathrm{r} & = & \text { Correlation coefficient } \\ \mathrm{N} & = & \text { Number of paired observations } \\ \mathrm{x}_{\mathrm{i}} & = & \text { Value of } \mathrm{x} \text { variable for } \mathrm{i}^{\text {th }} \\ \text { pair } & & \\ \mathrm{y}_{\mathrm{i}} & = & \text { Value of } \mathrm{y} \text { variable for } \mathrm{i}^{\text {th }} \\ \text { pair } & & \end{array}$

The significance of correlation coefficient was tested by ' $t$ ' value, which was measured by using following formula:

$$
\begin{aligned}
& t=\frac{r-\sqrt{N-2}}{\sqrt{1-r^{2}}} \\
& \text { d.f. }=\quad N-2
\end{aligned}
$$

The value of ' $r$ ' always lies between -1 to +1 . The positive value of ' $r$ ' indicates a tendency of ' $x$ ' and ' $y$ ' to increase together. Where ' $r$ ' is negative, large values of ' $x$ ' are associated with small values of ' $y$ '. For test of significance ' $r$ ' tabulated is located at (n-2) degrees of freedom.

\section{Relationship between socio-economic traits of women trainees with their Income generation}

The relationship between income generation of women trainees and the selected independent variables viz. their age, caste, occupation, education, social participation, marital status, land holding, type of house, mass media participation, vocational training received, economic motivation, market orientation and risk orientation were 
measured by computing "Coefficient of correlation (r)". The data have been presented in table 1 .

The values of coefficient of correlation furnished in table 1 clearly show that income of trained employed women was positively and significantly associated with education and mass media participation at $1 \%$ level of significance where as occupation, social participation, marital status, land holding, vocational training received, economic motivation, market orientation, risk orientation was positively and significant associated at $5 \%$ level of significance where as age, caste and type of house was positively and non significantly related with the income of trained women.

Table.1 Relationship of the selected independent variables with the income generation by the women trainees

\begin{tabular}{|l|l|c|}
\hline S. No. & Independent variables & Correlation coefficient (r) \\
\hline 1. & Age & 0.2271 \\
\hline $\mathbf{2 .}$ & Caste & 0.3182 \\
\hline $\mathbf{3 .}$ & Occupation & $0.3875^{*}$ \\
\hline $\mathbf{4 .}$ & Education & $0.5061^{* *}$ \\
\hline $\mathbf{5 .}$ & Social participation & $0.3596^{*}$ \\
\hline $\mathbf{6 .}$ & Marital status & $0.3369^{*}$ \\
\hline $\mathbf{7 .}$ & Land holding & $0.3818^{*}$ \\
\hline $\mathbf{8 .}$ & Type of house & 0.2579 \\
\hline $\mathbf{9 .}$ & Mass media participation & $0.4454^{* *}$ \\
\hline $\mathbf{1 0 .}$ & Vocational training received & $0.3352^{*}$ \\
\hline $\mathbf{1 1 .}$ & Economic motivation & $0.3442^{*}$ \\
\hline $\mathbf{1 2 .}$ & Market orientation & $0.4077^{*}$ \\
\hline $\mathbf{1 3}$ & Risk orientation & $0.3349^{*}$ \\
\hline
\end{tabular}

* Correlation is significant at the 0.05 level

** Correlation is significant at the 0.01 level

Hence, the null hypotheses $\mathrm{H}_{01.3}, \mathrm{H}_{01.4}, \mathrm{H}_{01.5}$, $\mathrm{H}_{01.6}, \mathrm{H}_{01.7}, \mathrm{H}_{01.9}, \mathrm{H}_{01.10}, \mathrm{H}_{01.11}, \mathrm{H}_{01.12}$ and $\mathrm{H}_{01.13}$ were rejected and alternate hypotheses were accepted, which shows that the women trainee's occupation, education, social participation, marital status, land holding, mass media participation, vocational training received, economic motivation, market orientation, risk orientation were significantly associated with income of women trainees. It can, therefore, be generalized that higher score of occupation, education, social participation, marital status, land holding, mass media participation, vocational training received, economic motivation, market orientation, risk orientation of the women trainees then higher would be their income.

It can be concluded that income of women trainees increases with the income in occupation. This might be due to the facts that women's occupation as dairy and agriculture with more land might have got more income. The educated women might have certainly learned more, understood more about the various activities of KVK due to their higher mental capabilities and use of latest technology and get maximum income. This 
might be due to the fact that the women trainees had more exposure by virtue of being member in different rural institutions like gram panchayat, block panchayat, village cooperative society, Kishan Mandal etc. leading to their active participation in social activities.The marital status was found significant relationship because married women have more responsibility about income generation on their own farms to increase income of family. The income has increased with the land holding. It might be because of more work on the large size of land holding as they might be taking more crops. Themass media participation of trained women's increase income in the fruit and vegetable preservation and increase knowledge because the knowledge leads more production increases their income. The vocational training received was increased their skill and skilled women get more income. Economic motivation of trained women is increased their income because trained women have knowledge about economically increased living standard of family. The market oriented women have knowledge about the market price of the product which is produced by them and increase their family income. The risk oriented women trainees, It is better for an entrepreneur women not to try new methods unless to be proved better by other women. Further, the trained women's age was found to have a positive and non-significant relationship with their income. It means that age did not have a significant effect on the income generating activities of the women trainees. It might be due to the reason that old aged women could not perform heavy work due to their mild attitude and their physical weakness. Caste and type of house was found to have a positive and non-significant relationship with their income means caste and type of house could not play any role in income generation of trained women. The present findings are in conformity with Jaiswal (2008) and Ali (2001).

\section{References}

Rajput, J. S.; Latoria, S. K.; Kakran, M.S. and Sharma, P. 2005 "Correlates of training needs of farm women in Krishi Vigyan Kendra, (M.P.)". Madhya J. Ext. Edu., 8.

Samantha, P.K. 1977 "A study of some agroeconomic, socio psychological and communication variables associated with repayment behaviour of agricultural credit users of nationalized bank", Ph.D. Thesis, BCKVV (W.B.) India.

Singh, A.P.; Singh, A. K. and Kumar, A. 2014 "Association of empowerment level and socio-economic condition of women in Harahua block of Varanasi, (U.P.)". Current Advances in Agril. Sci., 6(1).

Sultana, A. and Hossen, S.K. 2013 "Role of Employment in Women Empowerment: Evidence from Khulana City of Bangladesh". International J. Soc. Sci. Interdisciplinary $\quad$ Res., $\quad 2277$ 3630IJSSIR, 2 (7).

Yogendrarajah, R. 2012 "The impact of micro credit on women empowerment". International J. Res. in Commerce, Economics and Management, 2(5).

\section{How to cite this article:}

Rakesh Kumar Kansotia, Jagdish Prasad Yadav, Ajit Kumar Ghoslya, Nitesh Kumar Tanwar and Naresh Kumar Kumawat. 2020. Relationship between Socio-Economic Traits of Women Trainees with their Income Generation by Krishi Vigyan Kendra, Chomu (Jaipur) Rajasthan. Int.J.Curr.Microbiol.App.Sci. 9(03): 304-307. doi: https://doi.org/10.20546/ijcmas.2020.903.035 